Monika KARDACH, Paweł FUĆ, Marta MACIEJEWSKA, Marta GALANT

Poznan University of Technology (Politechnika Poznańska)

\title{
ANALYSIS OF AVAILABLE METHODS FOR RISK ASSESSMENT DEDICATED TO UNMANNED AERIAL VEHICLES
}

\section{Analiza dostępnych metod oceny ryzyka zagrożeń dedykowanych bezzalogowym statkom powietrznym}

\begin{abstract}
Aviation is becoming more and more popular. It is influenced, inter alia, by the development of general aviation (GA) and unmanned aerial vehicles (UAV). Due to the increasing number of qualified UAV users (in April 2018 there were 6846 operators in Poland with a valid certificate of qualifications) and those performing only recreational flights, it is important to ensure an acceptable level of risk in these operations. Using the available methods, the risk of five exemplary unmanned operations was assessed. The results were compared to determine their validity.
\end{abstract}

Keywords: risk assessment, unmanned aerial vehicles, matrix method

Streszczenie: Lotnictwo staje się coraz bardziej powszechne. Wptyw na to ma między innymi rozwój lotnictwa ogólnego (general aviation, GA) $i$ bezzałogowych statków powietrznych (BSP). Liczba kwalifikowanych użtkowników BSP (w kwietniu 2018 r. byto $w$ Polsce 6846 operatorów z ważnym świadectwem kwalifikacji) i tych wykonujacych tylko loty rekreacyjne zwiększa się. Istotne jest więc zapewnienie dopuszczalnego poziomu ryzyka zagrożeń $w$ tych operacjach. Za pomoca dostęnych metod oceniono ryzyko zagrożeń podczas pięciu przykładowych operacji bezzałogowych. Wyniki zestawiono ze soba celem określenia miarodajności otrzymanych rezultatów.

Słowa kluczowe: ocena ryzyka, bezzałogowe statki powietrzne, metoda matrycowa 


\section{Introduction}

Remotely Piloted Aircraft Systems (RPAS) are increasingly used not only for military purposes, where they come from, but also non-military ones: commercial and non-commercial. In civil aviation, the "Safety first" principle applies - safety is the most important, therefore in this area of business it is necessary to manage safety in order to keep the risk at least tolerated $[1,8]$. Unmanned operations are soon to take place in the integrated airspace, including urban areas. For this reason, it is crucial to ensure safety in the areas of their current and planned eligibility. The risk assessment methods for unmanned aerial vehicles (UAV) are still being developed. They are created on the basis of methods used in manned aviation and differ from each other by the level of assessment complexity, time-consuming and easy to interpret results. This article aims to compare the methods available, taking into account the above criteria and the answer to the question whether the use of each of these methods provides commensurate results.

\section{Risk assessment methods dedicated to RPAS}

The methods of risk assessment for RPAS operators should take into account, in particular, hazard sources, such as: conflict air traffic, terrain obstacles and surrounding airspace, meteorological conditions, ground operations, and other hazards (e.g. turbulence, birds, volcanic dust). Therefore, the Polish Civil Aviation Authority (CAA) proposed a method of risk assessment under the State Safety Program (SSP). It is a three-step matrix method in which each defined risk is assigned the probability of occurrence (table 1) and severity of potential damages that may occur as a result of its activation (table 2) [10].

Table 1

Quantifying the probability of unwanted event in the matrix method $[6,10]$

\begin{tabular}{|l|l|l|}
\hline \multicolumn{1}{|c|}{ Probability } & \multicolumn{1}{|c|}{ Meaning } & \multicolumn{1}{c|}{$\begin{array}{c}\text { Numerical } \\
\text { value }\end{array}$} \\
\hline Often & It will probably occur many times (it was common) & 5 \\
\hline From time to time & $\begin{array}{l}\text { It will probably occur from time to time (it occurred } \\
\text { uncommonly) }\end{array}$ & 4 \\
\hline Distant & $\begin{array}{l}\text { Probably will not occur, but it is possible (occurred } \\
\text { rarely) }\end{array}$ & 3 \\
\hline Unbelievable & Very unlikely to occur (the occurrence is unknown) & 2 \\
\hline Extremely unlikely & Almost unimaginable that it can ever occur & 1 \\
\hline
\end{tabular}


Table 2

Quantification of the severity of damage in the matrix method $[6,10]$

\begin{tabular}{|l|l|l|}
\hline \multicolumn{1}{|c|}{ Severity } & \multicolumn{1}{|c|}{ Meaning } & $\begin{array}{c}\text { Numerical } \\
\text { value }\end{array}$ \\
\hline Catastrophic & Equipment's destruction/many fatalities & A \\
\hline Dangerous & $\begin{array}{l}\text { Significantly lowering the margin of safety, physical discomfort or } \\
\text { workload of the operators to such an extent that they are uncertain } \\
\text { that they will do it }\end{array}$ & B \\
\hline Critical & $\begin{array}{l}\text { Significant reduction of safety margins, weakness of operators' } \\
\text { ability to cope with adverse conditions }\end{array}$ & C \\
\hline Marginal & Difficulties/ operational limitations & D \\
\hline Negligible & Little consequences & E \\
\hline
\end{tabular}

Based on the values assigned to the severity levels (tab. 2) and probabilities (tab. 1), a risk index matrix is created in tab. 3.

Table 3

Risk index matrix $[6,10]$

\begin{tabular}{|c|c|c|c|c|c|c|}
\hline \multirow{2}{*}{\multicolumn{2}{|c|}{ Risk probability }} & \multicolumn{5}{|c|}{ Risk severity } \\
\hline & & $\begin{array}{c}\text { Catastrophic } \\
\text { A }\end{array}$ & $\begin{array}{c}\text { Dangerous } \\
\text { B }\end{array}$ & $\begin{array}{c}\text { Critical } \\
\mathrm{C}\end{array}$ & $\begin{array}{c}\text { Marginal } \\
\text { D }\end{array}$ & $\begin{array}{c}\text { Negligible } \\
\text { E }\end{array}$ \\
\hline Often & 5 & $5 \mathrm{~A}$ & $5 B$ & $5 \mathrm{C}$ & $5 \mathrm{D}$ & $5 \mathrm{E}$ \\
\hline From time to time & 4 & $4 \mathrm{~A}$ & $4 \mathrm{~B}$ & $4 \mathrm{C}$ & $4 \mathrm{D}$ & $4 \mathrm{E}$ \\
\hline Distant & 3 & $3 \mathrm{~A}$ & $3 B$ & $3 \mathrm{C}$ & $3 \mathrm{D}$ & $3 \mathrm{E}$ \\
\hline Unbelievable & 2 & $2 \mathrm{~A}$ & $2 \mathrm{~B}$ & $2 \mathrm{C}$ & 2D & $2 \mathrm{E}$ \\
\hline Extremely unlikely & 1 & $1 \mathrm{~A}$ & $1 \mathrm{~B}$ & $1 \mathrm{C}$ & 1D & $1 \mathrm{E}$ \\
\hline
\end{tabular}

The matrix combines values previously assigned to probability levels (from 1 to 5) and severity (from A to E). They are then divided into three ranges of tolerance (tab. 4): the level of unacceptable, tolerated and acceptable risk.

The second organization that created a risk assessment method for Remotely Piloted Aircraft Systems operations is JARUS (Joint Authorities for Rulemaking on Unmanned Systems). They proposed Holistic Risk Model (HRM) which contains general frames to identify hazard sources, formulating hazards and maintaining acceptable risk level for every RPAS operation [7]. This model is presented in the document on the Specific Operations Risk Assessment (SORA). This model consists of six stages: identification of damages, hazards, hazard sources, acceptable level of damage, acceptable levels of hazard sources. The document also distinguishes three categories of damage related to UAV [7]:

1) accidents involving third parties on the ground,

2) accidents involving third parties in the air (collisions in the air),

3) destruction of the infrastructure. 


\section{Table 4}

Risk acceptability table, own elaboration based on [10]

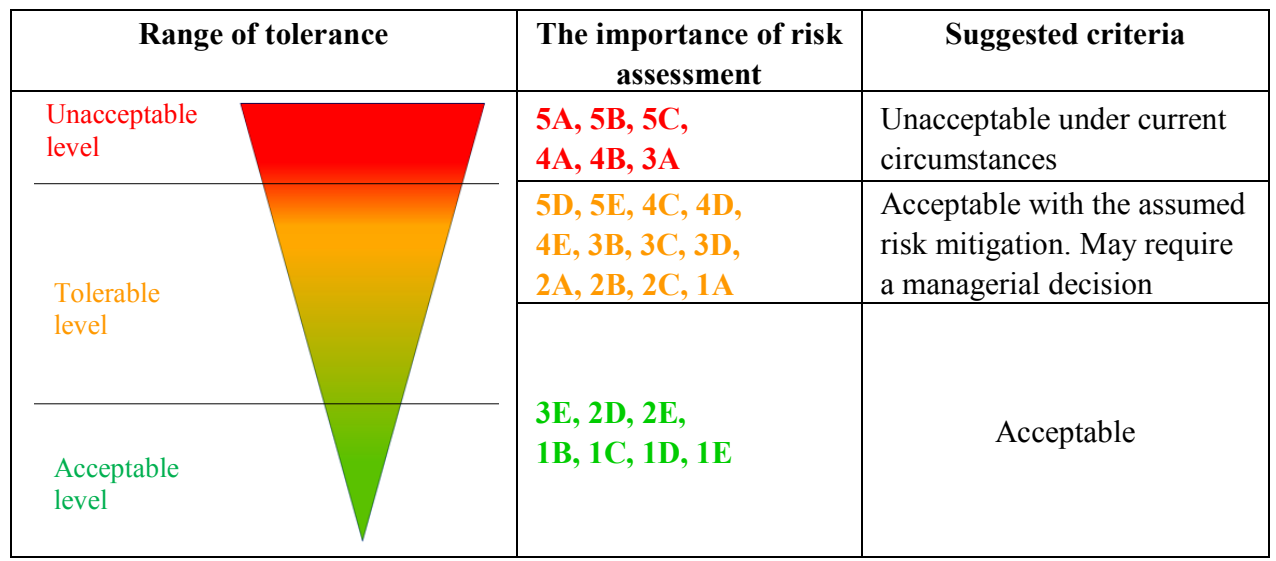

It was established that the only risk associated with UAV operations that could lead to the three categories of damage listed above is the broad issue of "UAV Out of Control", including loss of visual contact with RPAS, systematic technical problems, intrusions into airspace control areas, and more. To help identify hazard sources, they have been categorized [7]:

1) technical problems with an unmanned aircraft,

2) human error,

3) an aircraft on a collision course,

4) unfavorable operational conditions,

5) problems of external systems supporting UAV.

You can graphically present this problem using the Bow-tie method (fig. 1).

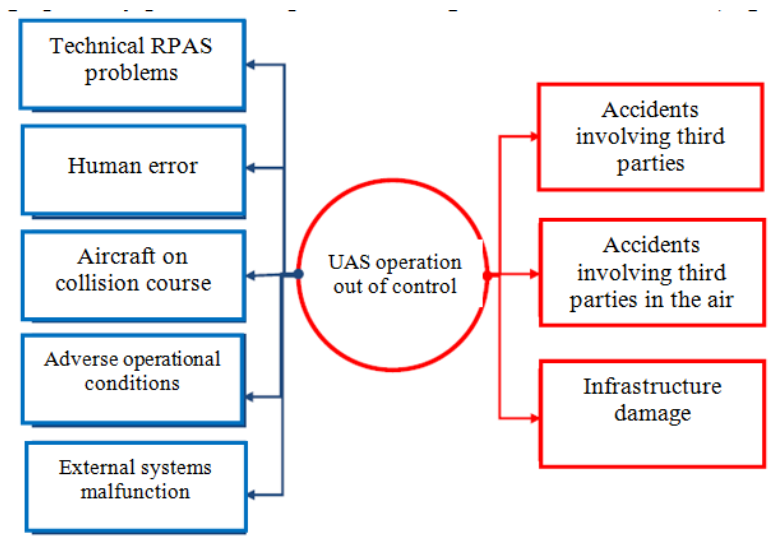

Fig. 1. HRM model represented by Bow-tie method, own elaboration based on [7] 
The HRM model assumes two complementary approaches to risk reduction in UAV operations: an approach reducing probabilities of an event and / or mitigating the effects of unwanted events for each category of damage. The so-called damage barriers and the reducing approaches are applied in order to decrease the probability that the UAS operation will be out of control by reducing the likelihood of the emergence of hazard sources. The first step to a good and complete risk analysis should be to collect enough technical, operational and human data related to the UAS process. It should be a description of the operation but also the safety culture prevailing in the organization. It is important to include such parts as: understanding definitions, organization structure, operators' obligations, the most risky areas of the activity, safety management system, design and production of UAV (if the organization is responsible for them), staff training, philosophy, procedures and maintenance strategy, pilots and support personnel responsibilities, qualifications certificates and aero-medical certificates, types of operations carried out (Visual Line Of Sight, Beyond Visual Line Of Sight, over people, far away from people, etc.), standard operating procedures, operational strategy, emergency and urgent operations, events reporting procedures, recruitment and training processes (description of training procedures and simulators if used), UAV description (dimensions, weight, center of gravity, materials, load transfer capabilities, on-board systems), UAV characteristics (performance, speed, wind speed limits, temperature, rain, ice), type and number of engines, the most sensitive points of the power system, description of navigation, autopilot, obstacle avoidance system (DAA, Detect And Avoid), Geofencing and others [10].

The second step is to determine the initial Ground Risk Class, GRC). It is a term referring to the uncorrected risk of an impact of a person on the ground by UAV when losing control over him. Aircrafts were divided according to their characteristic dimensions (wingspan for fixed wing aircraft, helicopter diameter for the helicopters and the maximum dimension for multirotors) and the expected kinetic energy during the impact. 11 GRC classes were distinguished as shown in tab. 5 .

The third point is safety barriers and GRC adaptation. This process step, allows to adapt the GRC based on the safety barriers available for specific operation. Table 6 lists the safety barriers and the corresponding correction factor. A positive number means an increase in the risk class, while a negative one results in a decrease. All barriers must be taken into account in order to carry out the assessment. 


\section{Table 5}

Initial Ground Risk Class [7]

\begin{tabular}{|c|c|c|c|c|}
\hline Max. Characteristic dimension of the UAV & $1 \mathrm{~m}$ & $3 \mathrm{~m}$ & $8 \mathrm{~m}$ & $>8 \mathrm{~m}$ \\
\hline Expected Kinetic Energy & $\begin{array}{c}<0,7 \\
\mathrm{~kJ}\end{array}$ & $<34 \mathrm{~kJ}$ & $\begin{array}{c}<1084 \\
\mathrm{~kJ}\end{array}$ & $\begin{array}{c}>1084 \\
\mathrm{~kJ}\end{array}$ \\
\hline \multicolumn{5}{|l|}{ Operational Scenarios } \\
\hline $\begin{array}{l}\text { VLOS in controlled airspace, over sparsely } \\
\text { populated area }\end{array}$ & 1 & 2 & 3 & 5 \\
\hline $\begin{array}{l}\text { BVLOS over sparsely populated area (formally } \\
\text { uninhabited) }\end{array}$ & 2 & 3 & 4 & 6 \\
\hline $\begin{array}{l}\text { VLOS in controlled airspace, over densely populated } \\
\text { area }\end{array}$ & 3 & 4 & 6 & 8 \\
\hline VLOS over densely populated area & 4 & 5 & 7 & 9 \\
\hline $\begin{array}{l}\text { BVLOS in controlled airspace, over densely } \\
\text { populated area }\end{array}$ & 5 & 6 & 8 & 10 \\
\hline BVLOS over densely populated area & 6 & 7 & 9 & 11 \\
\hline VLOS over gathering people & 7 & & & \\
\hline BVLOS over gathering people & 8 & & & \\
\hline
\end{tabular}

Table 6

List of example safety barriers with the corresponding corrective factor [7]

\begin{tabular}{|l|l|l|l|}
\hline \multirow{2}{*}{ Safety barriers for GRC } & \multicolumn{3}{c|}{ Resistance } \\
\cline { 2 - 5 } & $\begin{array}{l}\text { Low/ } \\
\text { none }\end{array}$ & Medium & High \\
\hline $\begin{array}{l}\text { The operator has access to an emergency response plan that is } \\
\text { effective }\end{array}$ & 1 & 0 & -1 \\
\hline $\begin{array}{l}\text { The effects of the collision with the ground are reduced (rescue } \\
\text { parachute) }\end{array}$ & 0 & -1 & -2 \\
\hline Effective technical protection & 0 & -2 & -4 \\
\hline
\end{tabular}

If the GRC can not be reduced to level 7 or below, the operation can not be considered sufficiently safe to perform in light of the SORA methodology [7].

Next, you should qualify the UAV for one of the three categories regarding mortality in the event of a UAV hit in a person on the ground. These categories are the subject of a broader study. Currently, it has been assumed that these are three categories: high, medium, low. Next, you can define a Specific Assurance and Integrity Level (SAIL) level to establish a sufficient level of certainty that the probability of losing control over the UAS operation is commensurate with the proposed initial assumptions. SAIL represents the level of confidence that the RPAS will remain under control. The SAIL level is not quantitative but a measure of goals to be met and may indicate the level of implementation. SAIL has been assigned to GRC using tab. 7. 


\section{Table 7}

Matrix for SAIL level specification [7]

\begin{tabular}{|c|c|c|c|c|c|c|c|}
\hline \multicolumn{8}{|c|}{ Ground Risk SAIL } \\
\hline \multirow[b]{2}{*}{ Mortality } & \multicolumn{7}{|c|}{ UAS GRC } \\
\hline & 7 & 6 & 5 & 4 & 3 & 2 & 1 \\
\hline High & VI & VI & $\mathrm{V}$ & IV & III & II & I \\
\hline Medium & VI & V & IV & III & II & I & 0 \\
\hline Low & $\mathrm{V}$ & IV & III & II & I & 0 & 0 \\
\hline
\end{tabular}

The next level of risk assessment includes the categorization of UAV operations in terms of the airspace in which they are performed. The SORA document proposes a division into 12 categories, as shown in tab. 8:

\section{Table 8}

Categorization of UAV operations in terms of space which they take place in [7]

\begin{tabular}{|l|l|}
\hline $\begin{array}{c}\text { Airspace } \\
\text { category } \\
\text { indicator }\end{array}$ & \multicolumn{1}{c|}{ Operational space } \\
\hline 1 & $\begin{array}{l}\text { Operations in airspace class A, B, C, D, E, F, except airport area above } 500 \mathrm{ft} . \\
\text { AGL }\end{array}$ \\
\hline 2 & Operations in airspace area above $500 \mathrm{ft}$. AGL \\
\hline 3 & Operations in G class above $500 \mathrm{ft}$. AGL with transponder \\
\hline 4 & Operations in G class above 500 ft. AGL above cities \\
\hline 5 & Operations in G class above $500 \mathrm{ft}$. AGL above rural area \\
\hline 6 & Operations in A-F classes except airport area $<500 \mathrm{ft}$. \\
\hline$\ldots$ & $\ldots$ \\
\hline
\end{tabular}

When the GRC is assessed, the procedure for determining the class of collision risk in the air (Air-Risk Class, ARC) should be started. It is based on three basic parameters: proximity indicator (the more aircrafts is in the air, the greater the probability of collisions), geometry (space that allows collision courses, increases the risk of collision: by controlling the geometry of the airspace structure by procedures and regulations, it decreases risk of collision), dynamics (the higher the aircraft velocity in space, the higher the probability of collision). ARCs take values from 1 to 4 , where 1 is the space in which the risk of collision between UAV and manned aircraft is low, and 4 is the space where the risk of collision between UAV and manned aircraft is high (tab. 9). 


\section{Table 9}

Air-Risk Class [7]

\begin{tabular}{|c|c|c|c|}
\hline & AEC & Operational space & ARC \\
\hline & 1 & $\begin{array}{l}\text { Operations in airspace class A, B, C, D, E, F, except airport } \\
\text { area above } 500 \mathrm{ft} \text {. AGL }\end{array}$ & 4 \\
\hline & $\ldots$ & $\ldots$ & $\ldots$ \\
\hline & $\mathrm{AEC}$ & Operational space & $\mathrm{ARC}$ \\
\hline \multirow{5}{*}{ 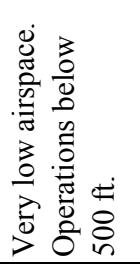 } & 6 & Operations in A-F classes except airport area $<500 \mathrm{ft}$. & 3 \\
\hline & 7 & Operations in airspace area below $500 \mathrm{ft}$. AGL & 4 \\
\hline & 8 & Operations in G class below $500 \mathrm{ft}$. AGL with transponder & 3 \\
\hline & 9 & Operations in G class below $500 \mathrm{ft}$. AGL above cities & 3 \\
\hline & 10 & Operations in G class below $500 \mathrm{ft}$. AGL above rural area & 2 \\
\hline $\begin{array}{l}\text { Very high } \\
\text { airspace }\end{array}$ & 11 & Operations in airspace above FL600 & 2 \\
\hline Other & 12 & $\begin{array}{l}\text { Operations in } \mathrm{R}, \mathrm{D} \text { zones, between buildings, other than } 1 \text { to } \\
11\end{array}$ & 1 \\
\hline
\end{tabular}

After defining the ARC value, strategic risk mitigation should be established. They are used to lower ARC. This effect can be obtained by: time restrictions (e.g. flying at night), spatial restrictions (limitation of flights to the assigned airspace), restrictions of exposure time (if flights are made in one zone but for a short period of time crosses the corner of another zone, then the risk in this piece of space is limited by a short exposure time), procedural separation (use of designated airspace geometries). After applying the reduction, ARC can be assigned to SAIL IV. Obtaining the desired level of tactic mitigation (ARC 3 = medium requirements) is the next step to completing the risk analysis. Tactical actions are to affect the collision risk remaining after the strategic procedure. It involves using procedures with a short time horizon (a few seconds to several minutes) in order to avoid collisions by dynamically changing the geometry according to the loop: notice, decide, avoid, analyze. Examples of tactical mitigations include: TCAS, ATC, MIDCAS, DAA. Identification of the recommended barriers to the hazard sources is the next step of the SORA process. The barriers should be associated with the highest SAIL obtained from GRC and ARC. Table 10 presents the methodology needed to perform these associations. The table assumes the following designations: $\mathrm{O}$ - optional, $\mathrm{L}$ - low resistance, $\mathrm{M}$ - medium resistance, $\mathrm{H}$ - high resistance. 


\section{Table 10}

Methodology of safety barrier associations with SAIL [7]

\begin{tabular}{|l|l|l|l|l|l|l|}
\hline & \multicolumn{6}{|c|}{ SAIL } \\
\hline & I & II & III & IV & V & VI \\
\hline Technical issue & & & & & & \\
\hline The operator is competent & O & L & M & H & H & H \\
\hline$\ldots$ & $\ldots$ & $\ldots$ & $\ldots$ & $\ldots$ & $\ldots$ & $\ldots$ \\
\hline Human factor & & & & & & \\
\hline Coordinated multi-person crew & L & L & M & H & H & H \\
\hline$\ldots$ & $\ldots$ & $\ldots$ & $\ldots$ & $\ldots$ & $\ldots$ & $\ldots$ \\
\hline $\begin{array}{l}\text { Deterioration of the operation of external } \\
\text { UAV support systems }\end{array}$ & & & & & & \\
\hline $\begin{array}{l}\text { UAV is designed to cope with the } \\
\text { deterioration of external systems }\end{array}$ & L & L & M & H & H & H \\
\hline$\ldots$ & $\ldots$ & $\ldots$ & $\ldots$ & $\ldots$ & $\ldots$ & $\ldots$ \\
\hline Unfavorable operational conditions & & & & & & \\
\hline $\begin{array}{l}\text { The operator is trained to recognize } \\
\text { unfavorable conditions and avoid them }\end{array}$ & O & L & M & M & M & H \\
\hline$\ldots$ & & & & & & \\
\hline
\end{tabular}

After this step, it is necessary to check the feasibility of the set barriers and operational scenarios, then to verify the resistance of the barriers used. The resistance determinations of each barrier determine both the level of integrity required to meet SAIL (e.g., the safety gain provided by each mitigation) and the level of assurance required to demonstrate the SAIL target has been met (e.g., evidence that the declared safety increase has been achieved). A low level of certainty is one for which the operator declares to achieve the required level of integrity. The average level of certainty is one for which the operator provides evidence of the required level of integrity. This is usually achieved by testing (for example for technical limitations) or by documenting the experience.

A high level of certainty is usually one for which approval of the achieved reliability has been accepted by a competent third party. After determining the level of integrity and confidence level for each barrier, the level of resistance can be determined. Using the available methods, it was decided to assess the risk during five exemplary unmanned operations: monitoring of line infrastructure, monitoring of air pollution, photography and video filming, precision agriculture and recreational flight in built-up areas. The results were compared with each other to determine the validity of the results obtained. 


\section{Risk assessment in the chosen area of the analysis}

According to the Federal Aviation Administration (FAA), the most popular UAV in the US used for non-recreational or sports purposes is DJI Phantom 4 (1375 g) [4], which is why it was chosen as a model for all commercial operations. It was assumed that the model UAV for recreational flights will be Syma X5HW with dimensions $33 \mathrm{~cm} \times 33 \mathrm{~cm} \times 11 \mathrm{~cm}$ and weight $200 \mathrm{~g}$. The model was chosen for good value for money according to the portal droniarze-sklep.pl. In order to determine the likelihood of occurrence of the event, statistics on aviation incidents in Europe in 2018 were analyzed [3]. Among 50 events, 15 concerned privacy violations of third parties, 11 related to criminal activity, 17 related to a collision with a manned aircraft, of which sixteen were avoided (in 8 cases, air traffic at the airport was stopped). Four events were related to the flight over the critical infrastructure, and 3 related to video filming during mass events (fig. 2).

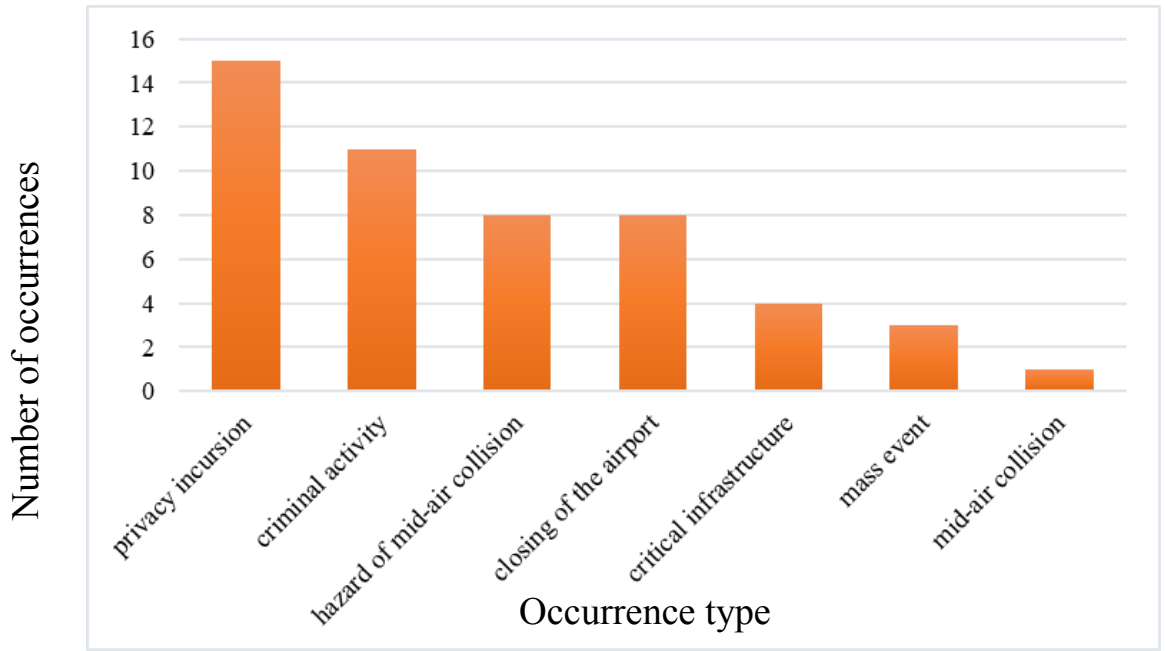

Fig. 2. Classification of aviation incidents in Europe with the participation of UAV [3]

Linear infrastructure monitoring was chosen as an example of an activity on which risk assessment will be carried out using two methods. The assessment process was also carried out for the remaining areas, and summary results are presented in Table 14. According to the classification (fig. 2), $8 \%$ of incidents took place over the critical infrastructure. Therefore, in the matrix method, the probability 3 was assigned to the event (it probably will not occur, but it is possible because it was rare before). The severity of the damage was assessed as B level due to the relatively large mass of $\mathrm{UAV}$, and the potential damage it is able to cause 
and may indirectly affect many people (e. g. loss of control over UAV while monitoring power lines may cause power outages). The operation thus obtained category 3B, which means: "risk acceptable under assumed risk mitigation. It may require a decision at the management level. "Risk mitigation measures can be, for example, choosing the right weather conditions to perform the operation, notifying the Polish Air Navigation Services Agency (PANSA) about the planned flight route, or setting the return to launch system (RTL) at the right height [9]. The assessment of the same operation using the HRM method was carried out according to the scheme described in chapter 2 . The sub-task concerning the evaluation of the organization was omitted due to the large diversity of security systems in the companies dealing with unmanned flights and this is their individual feature. The largest dimension of Phantom 4 drone is smaller than $1 \mathrm{~m}$, therefore, according to the method, the expected kinetic energy will be $<0.7 \mathrm{~kJ}$. Due to the fact that the chosen fragment of the linear infrastructure on the section of $2.5 \mathrm{~km}$ requires performing the operation out of sight (Beyond Visual Line Of Sight, BVLOS) and takes place mainly over the agricultural area (fig. 3).

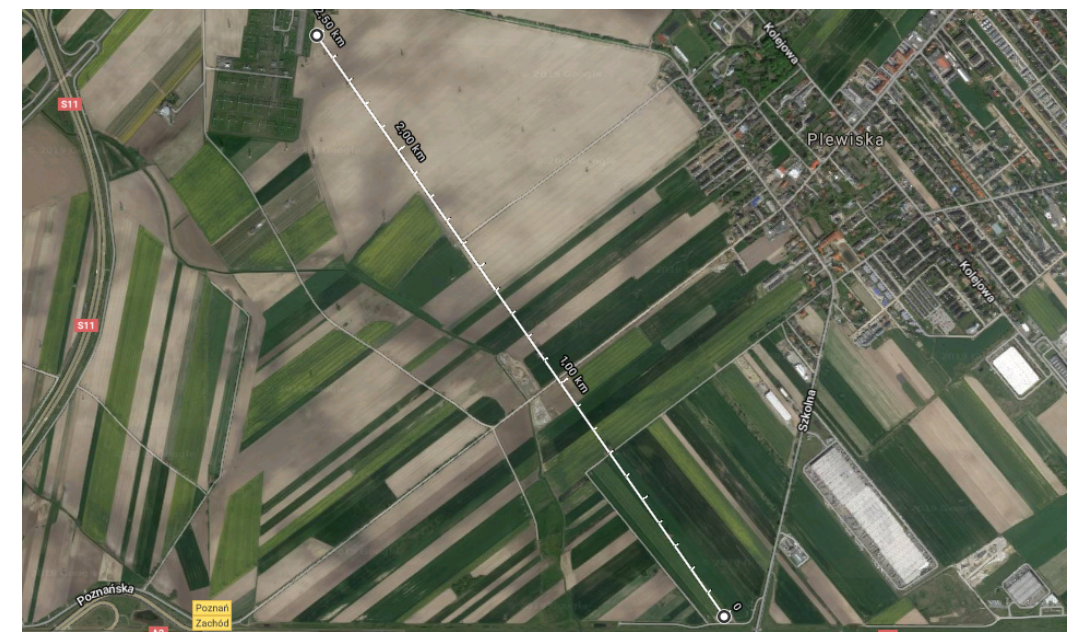

Fig. 3. A top view of the planned monitoring flight route [5]

The operator has access to the crisis response plan, made available by the company commissioning the monitoring but he was not able to check it, therefore the resistance of this barrier is medium, the unmanned aircraft does not have an emergency parachute, and there is no technical protection (table 6). GRC $\leq 7$ so the operation can be considered sufficiently safe according to the SORA methodology. Taking into account the potential mortality (flights are not carried out over a 
populated area), SAIL $=0$ was obtained (tab. 7). Then an assessment was made in terms of airspace. The flight is carried out in the Military Aerodrome Traffic zone (MATZ) of Poznan-Krzesiny airport, at an altitude of 150 - $200 \mathrm{ft}$. which allows for determining the airspace category index equal to 6 (table 8). This will allow to start the procedure for determining the ARC class $=3$ (tab. 9). The third class allows to define the level of certainty and safety integrity, which in this case is 4 (tab. 10), which leads to the mitigated risk mitigation requirements. A lot of emphasis should be placed on the operator's competencies and crew coordination. Measures should be taken to ensure the correct operation of the unmanned system in the event of deterioration of external devices, and adapt operating procedures to a specific operation (tab. 12). After verifying the feasibility of the set barriers and operational scenarios, the level of integrity and certainty is determined, which is, as the first point of the method, the operator's task and needs to be adapted to the real situation. Analyzes were carried out analogously to monitor air pollution, photography and video filming, precision agriculture and recreational flights in built-up areas (tab. 11).

Table 11

Comparison of analysis areas with available methods

\begin{tabular}{|l|c|c|c|}
\hline & $\begin{array}{c}\text { CAA } \\
\text { method }\end{array}$ & $\begin{array}{c}\text { JARUS method } \\
\text { GRC }\end{array}$ & JARUS method ARC \\
\hline Linear infrastructure & $3 \mathrm{~B}$ & 0 & IV \\
\hline Air pollution & 4B & V & VI \\
\hline Photography & $\mathbf{3 A}$ & VI & IV \\
\hline Agriculture & $1 \mathrm{D}$ & 0 & IV \\
\hline Recreational flights & $\mathbf{5 B}$ & III & IV \\
\hline
\end{tabular}

In each area of UAVs activity, in which one of the elements proposed by JARUS (GRC or ARC) appeared in the SAIL level > IV, the CAA method has an unacceptable level of risk. In order to monitor air pollution, as well as photography and video filming, consistent results were obtained in both methods. On recreational flights, the CAA method proved to be more restrictive and indicated an unacceptable level, while both GRC and ARC were tolerated. In two cases, when GRC was 0 and ARC IV, the methods did not give comparable results, because in one case the CAA method indicated acceptable and in the second tolerated level of risk. It can be concluded that the CAA method classifies the level of risk as higher than the JARUS method, which is positive for security reasons but does not meet the requirements of the rapidly growing industry. 


\section{Conclusion}

In order to compare the available methods, 5 areas of analysis were selected. The formulated hazards were analyzed in accordance with the methodologies and the results were compared. The CAA method is a reactive method [2] (based on past events) which is not appropriate for the specifics of the relatively new and dynamically growing UAV market in Poland. In the analysis, it was necessary to use the statistics of the European market, which does not accurately reflect the situation on the Polish market. In the database of the Polish National Transportation Safety Board, there is not enough applications to provide the basis for a method based on the frequency of similar events in the past. The method proposed by JARUS is more complex and makes it easier to find the exact area in which it is necessary to improve the level of risk and also provides tools for its mitigation. However, it is complicated for often single-man companies in the industry. Therefore, it is necessary to develop new methods to ensure safety and meet the expectations of users.

\section{References}

1. Fellner A., Mańka A.: Dostosowanie metody FMEA do wymagań branży lotniczej. Zeszyty Naukowe Politechniki Śląskiej. Seria Transport. 2015.

2. Galant M.: Ograniczenie ryzyka zagrożeń w lotnictwie ogólnym przez zastosowanie systemu monitorującego stan psychofizyczny pilota. Rozprawa doktorska. Politechnika Poznańska, Poznań 2017.

3. https://www.dedrone.com/resources/incidents/

4. https://uavcoach.com/faa-drone-data/

5. https://www.google.pl/maps/

6. International Civil Aviation Organization: Manual on Remotely Piloted Aircraft Systems (RPAS), Doc. 10019 ICAO, first edition 2016.

7. JARUS guidelines on Specific Operations Risk Assessment (SORA) 2017

8. Klich E.: Bezpieczeństwo lotów. Wydawnictwo Instytutu Technologii Eksploatacji, Radom 2011.

9. Rozporządzenie Ministra Transportu, Budownictwa i Gospodarki Morskiej z dnia 26 marca 2013 r. w sprawie wyłączenia zastosowania niektórych przepisów ustawy Prawo lotnicze do niektórych rodzajów statków powietrznych oraz określenia warunków i wymagań dotyczących używania tych statków.

10. Urząd Lotnictwa Cywilnego, Krajowy Plan Bezpieczeństwa 2017-2020, Warszawa, 2017. 


\section{ANALIZA DOSTĘPNYCH METOD OCENY RYZYKA ZAGROŻEŃ DEDYKOWANYCH BEZZALOGOWYM STATKOM POWIETRZNYM}

\section{Wprowadzenie}

Bezzałogowe statki powietrzne (BSP) są coraz częściej wykorzystywane nie tylko w celach militarnych, skąd się wywodzą, ale również pozamilitarnych: komercyjnych i niekomercyjnych. W lotnictwie cywilnym obowiązuje zasada Safety first - bezpieczeństwo jest najważniejsze, dlatego w tym obszarze działalności konieczne jest takie zarządzanie bezpieczeństwem, aby utrzymać ryzyko na poziomie co najmniej tolerowanym $[1,8]$. Operacje bezzałogowe już niedługo mają odbywać się w zintegrowanej przestrzeni powietrznej, łącznie zobszarami miejskimi. Z tego względu kluczowe jest zapewnienie bezpieczeństwa wobszarach ich obecnej i planowanej działalności. Wciąż rozwijane są metody oceny ryzyka operacji bezzałogowych statków powietrznych (BSP). Tworzone są one na podstawie metod wykorzystywanych w lotnictwie załogowym i różnią się od siebie poziomem złożoności oceny, czasochłonnością i łatwością interpretacji wyników. Niniejszy artykuł ma na celu porównanie dostępnych metod z uwzględnieniem powyższych kryteriów i odpowiedź na pytanie, czy stosowanie każdej z tych metod zapewnia współmierne rezultaty.

\section{Metody analizy ryzyka dedykowane bezzałogowym statkom powietrznym}

Metody oceny ryzyka zagrożeń dla operatorów BSP powinny uwzględniać szczególnie źródła zagrożeń, takie jak: konfliktowy ruch lotniczy, przeszkody terenowe i przestrzeń wokół, warunki meteorologiczne, operacje naziemne oraz inne zagrożenia (np. turbulencje, ptaki, pył wulkaniczny). W związku z tym, Urząd Lotnictwa Cywilnego (ULC) zaproponował metodę oceny ryzyka w ramach Krajowego Programu Bezpieczeństwa w Lotnictwie Cywilnym (KPBwLC). Jest to metoda matrycowa trójstopniowa, w której każdemu zdefiniowanemu zagrożeniu przypisuje się prawdopodobieństwo wystąpienia (tab. 1) i dotkliwość potencjalnych szkód mogących wystąpić w wyniku jego aktywacji (tab. 2) [10]. 
Tabela 1

Ilościowe określenie prawdopodobieństwa wystąpienia zdarzenia w metodzie matrycowej $[6,10]$

\begin{tabular}{|l|l|l|}
\hline Prawdopodobieństwo & \multicolumn{1}{|c|}{ Znaczenie } & $\begin{array}{l}\text { Wartość } \\
\text { liczbowa }\end{array}$ \\
\hline Częste & Prawdopodobnie wystąpi wiele razy (występowało często) & 5 \\
\hline Sporadyczne & $\begin{array}{l}\text { Prawdopodobnie wystąpi od czasu do czasu (występowało } \\
\text { niezbyt często) }\end{array}$ & 4 \\
\hline Dalekie & $\begin{array}{l}\text { Prawdopodobnie nie wystąpi, ale jest to możliwe } \\
\text { (występowało rzadko) }\end{array}$ & 3 \\
\hline Nieprawdopodobne & $\begin{array}{l}\text { Bardzo mało prawdopodobne, że wystąpi (przypadek } \\
\text { wystąpienia nie jest znany) }\end{array}$ & 2 \\
\hline $\begin{array}{l}\text { Skrajnie } \\
\text { nieprawdopodobne }\end{array}$ & Prawie niewyobrażalne, że kiedykolwiek może wystąpić & 1 \\
\hline
\end{tabular}

Tabela 2

Ilościowe określenie dotkliwości szkód w metodzie matrycowej [6, 10]

\begin{tabular}{|l|l|l|}
\hline \multicolumn{1}{|c|}{ Dotkliwość } & \multicolumn{1}{|c|}{ Znaczenie } & $\begin{array}{l}\text { Wartość } \\
\text { liczbowa }\end{array}$ \\
\hline Katastrofalna & Zniszczenie sprzętu/ wiele ofiar śmiertelnych & A \\
\hline Niebezpieczna & $\begin{array}{l}\text { Duże obniżenie marginesu bezpieczeństwa, fizyczne dolegliwości } \\
\text { lub obciążenie operatorów pracą w takim stopniu, że nie ma } \\
\text { pewności, że ją wykonają }\end{array}$ & B \\
\hline Większa & $\begin{array}{l}\text { Znaczne zredukowanie marginesów bezpieczeństwa, osłabienie } \\
\text { zdolności operatorów do radzenia sobie z niekorzystnymi } \\
\text { warunkami }\end{array}$ & C \\
\hline Niewielka & Uciążliwość/ ograniczenia operacyjne & D \\
\hline Nieistotna & Niewielkie konsekwencje & E \\
\hline
\end{tabular}

Na podstawie wartości przypisanych do poziomów szkód i prawdopodobieństwa w tabelach 1 i 2 tworzona jest matryca indeksu ryzyka (tab. 3).

Tabela 3

Matryca indeksu ryzyka zagrożeń $[6,10]$

\begin{tabular}{|c|c|c|c|c|c|c|}
\hline \multirow{2}{*}{\multicolumn{2}{|c|}{$\begin{array}{c}\text { Prawdopodobieństwo } \\
\text { ryzyka }\end{array}$}} & \multicolumn{5}{|c|}{ Dotkliwość ryzyka } \\
\hline & & $\begin{array}{c}\text { Katastrofalna } \\
\mathbf{A}\end{array}$ & $\begin{array}{c}\text { Niebezpieczna } \\
\text { B }\end{array}$ & $\begin{array}{c}\text { Poważna } \\
\text { C }\end{array}$ & $\begin{array}{c}\text { Niewielka } \\
\text { D }\end{array}$ & $\begin{array}{c}\text { Nieistotna } \\
\mathbf{E}\end{array}$ \\
\hline Częste & 5 & $5 \mathbf{A}$ & 5B & $5 \mathrm{C}$ & $5 \mathrm{D}$ & $5 \mathrm{E}$ \\
\hline Sporadyczne & 4 & $4 \mathrm{~A}$ & 4B & $4 \mathrm{C}$ & $4 \mathrm{D}$ & $4 \mathrm{E}$ \\
\hline Dalekie & 3 & $3 \mathbf{A}$ & $3 \mathrm{~B}$ & $3 \mathrm{C}$ & $3 \mathrm{D}$ & $3 \mathrm{E}$ \\
\hline Nieprawdopodobne & 2 & $2 \mathrm{~A}$ & $2 B$ & $2 \mathrm{C}$ & $2 \mathrm{D}$ & $2 \mathrm{E}$ \\
\hline $\begin{array}{l}\text { Skrajnie } \\
\text { nieprawdopodobne }\end{array}$ & 1 & 1A & 1B & $1 \mathrm{C}$ & 1D & $1 \mathrm{E}$ \\
\hline
\end{tabular}


W matrycy zestawia się ze sobą wartości przypisane wcześniej poziomom prawdopodobieństwa (od 1 do 5) oraz dotkliwości (od A do E). Następnie dzieli się je na trzy zakresy tolerancji (tabela 4): poziom ryzyka nieakceptowanego, tolerowanego i akceptowalnego.

\section{Tabela 4}

Tabela akceptowalności ryzyka, opracowanie własne na podstawie [10]

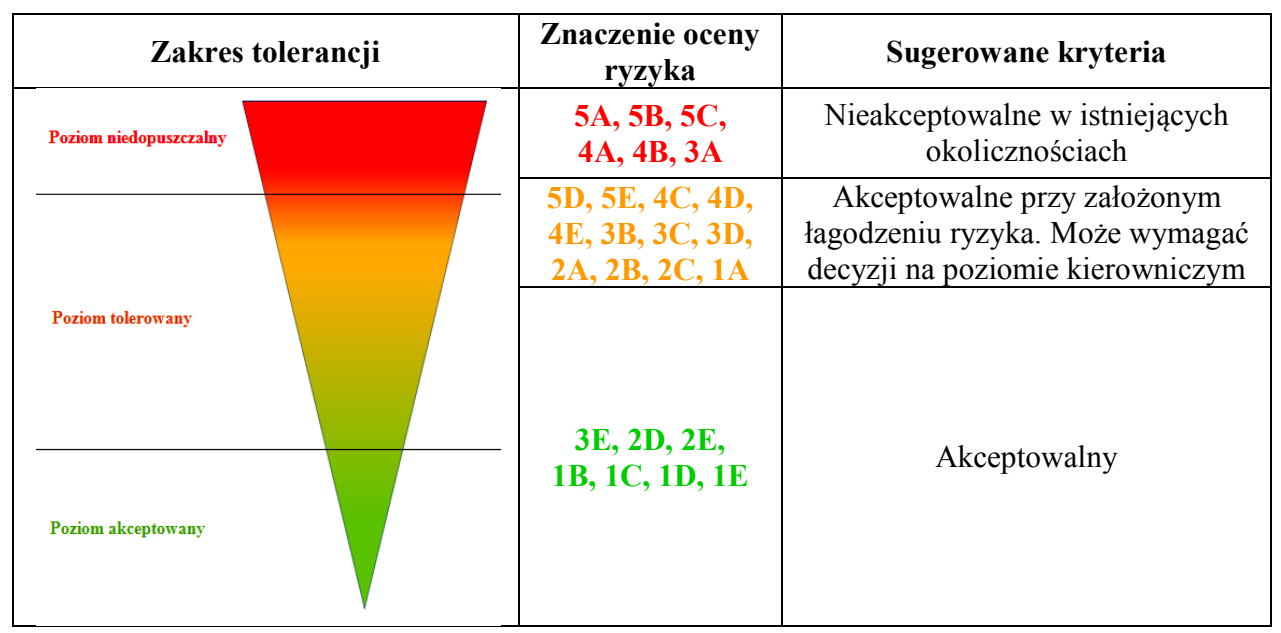

Drugą organizacją proponującą metodę oceny ryzyka dla operacji BSP jest JARUS (Joint Authorities for Rulemaking on Unmanned Systems). Proponowany holistyczny model ryzyka (Holistic Risk Model, HRM) zapewnia ogólne ramy do identyfikacji źródeł zagrożeń, formułowania zagrożeń, utrzymywania ryzyka na poziomie akceptowanym i ma zastosowanie do każdej operacji BSP [7]. Model ten przedstawiony jest $\mathrm{w}$ dokumencie na temat szacowania ryzyka operacji charakterystycznych (Specific Operations Risk Assessment, SORA). Model ten składa się z sześciu etapów: identyfikacji szkód, zagrożeń, źródeł zagrożeń, dopuszczalnego poziomu szkód, dopuszczalnych poziomów źródeł zagrożeń. W dokumencie wyróżniono również trzy kategorie szkód związane z UAV [7]:

1) wypadki z udziałem osób trzecich na ziemi,

2) wypadki z udziałem osób trzecich w powietrzu (kolizje w powietrzu),

3) zniszczenia infrastruktury.

Ustalono, że jedynym zagrożeniem powiązanym z operacjami UAV, które może prowadzić do wymienionych powyżej trzech kategorii szkód jest szerokie zagadnienie „Operacja UAV poza kontrolą”, obejmujące utratę kontaktu wzrokowego z BSP, systemowe problemy techniczne, wtargnięcia $\mathrm{w}$ obszary kontrolowane przestrzeni powietrznej i inne. Aby ułatwić identyfikację źródeł zagrożeń, podzielono je na kategorie [7]: 
1) problemy techniczne $z$ bezzałogowym statkiem powietrznym,

2) błąd ludzki,

3) statek powietrzny na kursie kolizyjnym,

4) niekorzystne warunki operacyjne,

5) problemy systemów zewnętrznych obsługujących BSP.

Graficznie można przedstawić ten problem za pomocą metody Bow-tie (rys. 1).

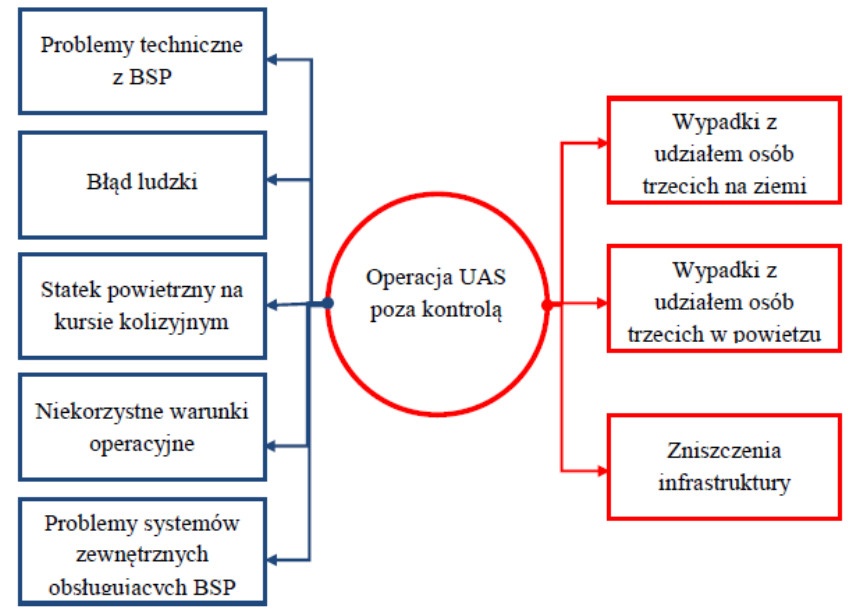

Rys. 1. Model HRM zaprezentowany za pomocą Bow-tie, opr. własne na podst. [7]

Model HRM zakłada dwa komplementarne podejścia do redukcji ryzyka w operacjach BSP: podejście redukujące prawdopodobieństwa zdarzenia i/ lub łagodzenie skutków zdarzeń niepożądanych dla każdej kategorii szkód. Aplikuje się w tym celu tzw. bariery szkód i podejście redukujące prawdopodobieństwo, że operacja UAS znajdzie się poza kontrolą przez redukcję prawdopodobieństwa pojawienia się źródeł zagrożeń. W tym celu aplikuje się tzw. bariery źródeł zagrożeń. Pierwszym krokiem do dobrej i kompletnej analizy ryzyka powinno być zebranie wystarczającej ilości danych technicznych, operacyjnych i dotyczących ludzi zaangażowanych w proces użytkowania UAS. Powinien być to opis operacji, ale też kultury bezpieczeństwa panującej $\mathrm{w}$ organizacji. Ważne jest, aby zawierał takie działy jak: rozumienie definicji, struktura organizacji, obowiązki operatorów, najbardziej ryzykowne obszary działalności, system zarządzania bezpieczeństwem, projektowanie i produkcja BSP (jeśli organizacja za nie odpowiada), kształcenie kadr, filozofia, procedury i strategia utrzymania zdatności, obowiązki pilotów i personelu wspierającego, świadectwa kwalifikacji i orzeczenia lotniczo-lekarskie, rodzaje przeprowadzanych operacji (w zasięgu wzroku, poza zasięgiem wzroku, nad ludźmi, daleko 
od ludzi itd.), standardowe procedury operacyjne, strategia operacyjna, operacje wyjątkowe i nagłe, procedury raportowania o zdarzeniach, procesy rekrutacji i szkoleń (opis procedur szkoleń i symulatorów, jeśli są używane), opis BSP (wymiary, masa, środek ciężkości, materiały, możliwości przenoszenia ładunków, systemy pokładowe), charakterystyka BSP (osiągi, prędkości, limity prędkości wiatru, temperatury, deszczu, lodu), typ i ilość silników, najbardziej newralgiczne punkty systemu zasilania, opis nawigacji, autopilota, systemu unikania przeszkód (DAA, Detect And Avoid), Geofencing i inne [10]. Drugim krokiem jest określenie początkowej klasy ryzyka naziemnego Ground Risk Class, GRC). Jest to termin odnoszący się do niekorygowanego ryzyka uderzenia osoby znajdującej się na ziemi przez BSP przy utracie kontroli nad nim. Statki powietrzne podzielono wedhug ich wymiarów charakterystycznych (rozpiętości skrzydeł dla stałopłatów, średnicy śmigła dla śmigłowców i maksymalnego wymiaru dla multirotorów) i spodziewanej energii kinetycznej podczas uderzenia. Wyróżniono 11 klas GRC, jak przedstawiono w tab. 5.

Tabela 5

Pierwotne klasy ryzyka naziemnego [7]

\begin{tabular}{|c|c|c|c|c|}
\hline $\begin{array}{c}\text { Max. wymiar charakterystyczny } \\
\text { BSP } \\
\end{array}$ & $1 \mathbf{m}$ & $3 \mathbf{m}$ & $8 \mathrm{~m}$ & $>8 \mathrm{~m}$ \\
\hline Oczekiwana energia kinetyczna & $<0,7 \mathrm{~kJ}$ & $<34 \mathrm{~kJ}$ & $<1084 \mathrm{~kJ}$ & $>1084 \mathrm{~kJ}$ \\
\hline \multicolumn{5}{|l|}{ Scenariusze operacyjne } \\
\hline $\begin{array}{l}\text { VLOS w obszarze kontrolowanym, } \\
\text { nad obszarem rzadko zaludnionym }\end{array}$ & 1 & 2 & 3 & 5 \\
\hline $\begin{array}{l}\text { BVLOS nad obszarem rzadko } \\
\text { zaludnionym (formalnie } \\
\text { niezabudowanym) }\end{array}$ & 2 & 3 & 4 & 6 \\
\hline $\begin{array}{l}\text { VLOS w obszarze kontrolowanym, } \\
\text { nad obszarem gęsto zaludnionym }\end{array}$ & 3 & 4 & 6 & 8 \\
\hline $\begin{array}{l}\text { VLOS nad obszarem gęsto } \\
\text { zaludnionym }\end{array}$ & 4 & 5 & 7 & 9 \\
\hline $\begin{array}{l}\text { BVLOS w przestrzeni kontrolowanej } \\
\text { nad obszarem gęsto zaludnionym }\end{array}$ & 5 & 6 & 8 & 10 \\
\hline $\begin{array}{l}\text { BVLOS nad obszarem gęsto } \\
\text { zaludnionym }\end{array}$ & 6 & 7 & 9 & 11 \\
\hline VLOS nad zbiorowiskami ludzi & 7 & & & \\
\hline BVLOS nad zbiorowiskami ludzi & 8 & & & \\
\hline
\end{tabular}

Punkt trzeci to bariery bezpieczeństwa i adaptacja GRC. Ten krok procesu pozwala na adaptację GRC opartej na barierach bezpieczeństwa dostępnych dla danej operacji. W tab. 6 przedstawiono listę barier bezpieczeństwa i odpowiadający im czynnik korekcyjny. Znak dodatni oznacza zwiększenie klasy ryzyka, natomiast 
ujemny skutkuje jej obniżeniem. W celu przeprowadzenia oceny wszystkie bariery muszą być wzięte pod uwagę.

Tabela 6

Lista przykładowych barier bezpieczeństwa z odpowiadającym czynnikiem korekcyjnym [7]

\begin{tabular}{|l|l|l|l|}
\hline \multirow{2}{*}{ Bariery bezpieczeństwa dla GRC } & \multicolumn{3}{c|}{ Odporność } \\
\cline { 2 - 4 } & $\begin{array}{r}\text { Niska/ } \\
\text { żadna }\end{array}$ & Średnia & Wysoka \\
\hline $\begin{array}{l}\text { Operator ma dostęp do planu reagowania kryzysowego, } \\
\text { który jest skuteczny }\end{array}$ & 1 & 0 & -1 \\
\hline $\begin{array}{l}\text { Skutki zderzenia z ziemią są zredukowane (spadochron } \\
\text { ratunkowy) }\end{array}$ & 0 & -1 & -2 \\
\hline Skuteczne zabezpieczenie techniczne & 0 & -2 & -4 \\
\hline
\end{tabular}

Jeśli GRC nie może być zredukowana do poziomu 7 lub niższego, to operacja nie może być uznana za dostatecznie bezpieczną do wykonania w świetle metodologii SORA [7]. Następnie należy zakwalifikować BSP do jednej z trzech kategorii dotyczących śmiertelności w razie uderzenia BSP w osobę na ziemi. Kategorie te są tematem do szerszych badań. Obecnie przyjęto, że są to trzy kategorie: wysoka, średnia, niska. Następnie można zdefiniować poziom pewności i nienaruszalności bezpieczeństwa (Specific Assurance and Integrity Levels, SAIL), w celu ustalenia wystarczającego poziomu pewności, że prawdopodobieństwo utraty kontroli nad operacją UAS jest współmierne do proponowanych założeń początkowych. SAIL reprezentuje poziom pewności, że operacja BSP pozostanie pod kontrolą. Poziom SAIL nie jest ilościowy, ale jest miarą celów do spełnienia i może wskazywać na poziom ich realizacji. SAIL został przypisany do GRC za pomocą tab. 7.

Tabela 7

Matryca do określania poziomu SAIL [7]

\begin{tabular}{|l|l|l|l|l|l|l|l|}
\hline \multicolumn{7}{|c|}{ Ryzyko naziemne SAIL } \\
\hline \multirow{2}{*}{ Śmiertelnośćc } & \multicolumn{7}{|c|}{ UAS GRC } \\
\cline { 2 - 9 } & 7 & 6 & 5 & 4 & 3 & 2 & 1 \\
\hline Wysoka & VI & VI & V & IV & III & II & I \\
\hline Średnia & VI & V & IV & III & II & I & 0 \\
\hline Niska & V & IV & III & II & I & 0 & 0 \\
\hline
\end{tabular}

Następny poziom oceny ryzyka obejmuje kategoryzacje operacji UAV pod względem przestrzeni powietrznej, w której są wykonywane. Dokument SORA proponuje podział na 12 kategorii, jak przedstawiono w tab. 8: 


\section{Tabela 8}

Kategoryzacja operacji UAV pod względem przestrzeni, w której się odbywają [7]

\begin{tabular}{|l|l|}
\hline $\begin{array}{c}\text { Wskaźnik } \\
\text { kategorii } \\
\text { przestrzeni } \\
\text { powietrznej }\end{array}$ & \\
\hline 1 & $\begin{array}{l}\text { Operacje w przestrzeni klasy A, B, C, D, E, F, poza przetrzenią lotniskową } \\
\text { powyżej 500 ft. AGL }\end{array}$ \\
\hline$\ldots$ & $\ldots$ \\
\hline 6 & Operacje w klasach A-F poza przestrzenią lotniskową $<500 \mathrm{ft}$. \\
\hline$\ldots$ & $\ldots$ \\
\hline 12 & Operacje w strefach R, D, między budynkami, inne niż od 1-11 \\
\hline
\end{tabular}

Gdy oceniona zostanie GRC, należy rozpocząć procedurę wyznaczania klasy ryzyka kolizji w powietrzu (Air-Risk Class, ARC). Opiera się ona na trzech podstawowych parametrach: wskaźniku bliskości (im więcej SP jest w powietrzu, tym większe prawdopodobieństwo kolizji), geometrii (przestrzeń, która pozwala na kursy kolizyjne, zwiększa ryzyko kolizji: kontrolując geometrię struktury przestrzeni powietrznej przez procedury i regulacje, zmniejsza się ryzyko kolizji), dynamiki (im większa prędkość SP w przestrzeni, tym większe prawdopodobieństwo wystąpienia kolizji). ARC przyjmują wartości od 1 do 4, gdzie 1 oznacza przestrzeń, w której ryzyko kolizji BSP i załogowego statku powietrznego (ZSP) jest przyjmowanie małe, a 4 oznacza przestrzeń, w której ryzyko kolizji między BSP, a ZSP jest wysoka (tab. 9).

Po określeniu wartości ARC należy ustanowić strategiczne mitygacje ryzyka. Stosuje się je, aby obniżyć ARC. Efekt ten można uzyskać przez: restrykcje czasowe (np. latanie nocą), restrykcje przestrzenne (ograniczenie lotów do przypisanej przestrzeni powietrznej), restrykcje czasu ekspozycji (jeśli loty wykonywane są w jednej strefie, ale na krótki czas przetnie się róg innej strefy, to ryzyko w tym kawałku przestrzeni jest ograniczone przez krótki czas ekspozycji), separacji proceduralnej (korzystanie $\mathrm{z}$ wyznaczonych geometrii przestrzeni powietrznej). Po zastosowaniu redukcji można przypisać ARC do SAIL IV. Uzyskanie pożądanego poziomu mitygacji (dla poziomu ARC 3 wymagania dotyczące mitygacji taktycznych są umiarkowane) taktycznych jest kolejnym krokiem do ukończenia analizy ryzyka. Działania taktyczne mają oddziaływać na ryzyko kolizji pozostałe po procedurze strategicznej. Polega na zastosowaniu procedur o krótkim horyzoncie czasowym (kilka sekund do kilku minut) w celu uniknięcia kolizji przez dynamiczną zmianę geometrii według pętli: zauważ, zdecyduj, uniknij, przeanalizuj. Przykłady mitygacji taktycznych to m.in.: TCAS, ATC, MIDCAS, DAA. Identyfikacja rekomendowanych barier źródeł zagrożeń 
jest następnym krokiem procesu SORA. Bariery powinny być skojarzone z najwyższym SAIL otrzymanym z GRC i ARC. W tab. 10 przedstawiono metodykę potrzebną do wykonania tych skojarzeń. W tabeli przyjęto oznaczenia: $\mathrm{O}$ opcjonalny, L - niska odporność, M - średnia odporność, H - wysoka odporność.

Tabela 9

\section{Klasy ryzyka kolizji w powietrzu [7]}

\begin{tabular}{|c|c|c|c|}
\hline & AEC & Przestrzeń operacyjna & ARC \\
\hline & 1 & $\begin{array}{l}\text { Operacje w przestrzeni klasy A, B, C, D, E, F, poza przestrzenią } \\
\text { lotniskową powyżej } 500 \mathrm{ft} \text {. AGL }\end{array}$ & 4 \\
\hline & & $\ldots$ & \\
\hline \multirow{5}{*}{ 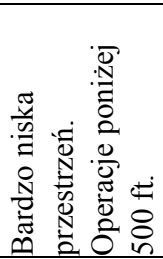 } & 6 & $\begin{array}{l}\text { Operacje w klasie } \mathrm{A}, \mathrm{B}, \mathrm{C}, \mathrm{D}, \mathrm{E}, \mathrm{F} \text { poza przestrzenią lotniskową } \\
\text { poniżej } 500 \mathrm{ft} \text {. AGL }\end{array}$ & 3 \\
\hline & 7 & Operacje w przestrzeni lotniskowej poniżej $500 \mathrm{ft}$. AGL & 4 \\
\hline & 8 & Operacje w klasie G poniżej $500 \mathrm{ft}$. AGL z transponderem & 3 \\
\hline & 9 & Operacje w klasie G poniżej $500 \mathrm{ft}$. AGL nad terenem miejskim & 3 \\
\hline & 10 & Operacje w klasie G poniżej $500 \mathrm{ft}$. AGL nad terenem wiejskim & 2 \\
\hline $\begin{array}{l}\text { B. wysoka } \\
\text { przestrzeń }\end{array}$ & 11 & Operacje w przestrzeni powyżej FL600 & 2 \\
\hline Inne & 12 & Operacje w strefach R, D, między budynkami, inne niż od 1-11 & 1 \\
\hline
\end{tabular}

Tabela 10

Metodyka skojarzeń barier bezpieczeństwa z SAIL [7]

\begin{tabular}{|l|l|l|l|l|l|l|}
\hline & \multicolumn{5}{|c|}{ SAIL } \\
\hline & I & II & III & IV & V & VI \\
\hline Kwestie techniczne & & & & & & \\
\hline Operator jest kompetentny & O & L & M & H & H & H \\
\hline $\begin{array}{l}\text { BSP zaprojektowany z uwzględnieniem } \\
\text { systemów bezpieczeństwa }\end{array}$ & O & O & L & M & H & H \\
\hline Czynnik ludzki & & & & & & \\
\hline Skoordynowana załoga wieloosobowa & L & L & M & H & H & H \\
\hline $\begin{array}{l}\text { Ustalone odpowiednie czasy odpoczynku } \\
\text { operatorów }\end{array}$ & L & L & M & M & H & H \\
\hline $\begin{array}{l}\text { Pogorszenia działania zewnętrznych } \\
\text { systemów wspomagających obsługę BSP }\end{array}$ & & & & & & \\
\hline $\begin{array}{l}\text { Usługi zewnętrzne obsługujące BSP są } \\
\text { adekwatne do operacji }\end{array}$ & L & L & M & H & H & H \\
\hline Niekorzystne warunki operacyjne & & & & & & \\
\hline $\begin{array}{l}\text { Procedury operacyjne są zdefiniowane, } \\
\text { zatwierdzone i przestrzegane }\end{array}$ & L & M & H & H & H & H \\
\hline$\ldots$ & $\ldots$ & $\ldots$ & $\ldots$ & $\ldots$ & $\ldots$ & $\ldots$ \\
\hline
\end{tabular}


Po tym etapie konieczne jest sprawdzenie wykonalności zadanych barier i scenariuszy operacyjnych, następnie weryfikacja odporności zastosowanych barier. Oznaczenia odporności każdej bariery określają zarówno poziom integralności wymagany do spełnienia SAIL (np. zysk bezpieczeństwa zapewniany przez każde złagodzenie), jak i poziom zapewnienia wymagany do wykazania celu SAIL został spełniony (np. dowód, że deklarowany wzrost odporności został osiągnięty). Niski poziom pewności to taki, za który operator deklaruje osiągnięcie wymaganego poziomu integralności. Średni poziom pewności to taki, za który operator dostarcza dowody potwierdzające wymagany poziom uczciwości. Zwykle osiąga się to poprzez testowanie (na przykład w celach technicznych ograniczeń) lub przez udokumentowanie doświadczenia. Wysoki poziom pewności to zazwyczaj taki, dla którego zatwierdzenie osiągniętej rzetelności zostało zaakceptowane przez kompetentną stronę trzecią. Po ustaleniu poziomu uczciwości i poziomu pewności dla każdej bariery, poziom odporności może zostać wyznaczony. Za pomocą dostępnych metod postanowiono ocenić ryzyko zagrożeń podczas pięciu przykładowych operacji bezzałogowych: monitorowanie infrastruktury liniowej, monitorowanie zanieczyszczenia powietrza, fotografia i wideofilmowanie, rolnictwo precyzyjne oraz lot rekreacyjny na terenie zabudowanym. Wyniki zestawiono ze sobą celem określenia miarodajności otrzymanych wyników.

\section{Ocena ryzyka zagrożeń $w$ wybranych obszarach analiz}

Według Federalnej Administracji Lotnictwa najpopularniejszym BSP w Stanach Zjednoczonych używanym w celach innych niż rekreacyjne lub sportowe jest DJI Phantom 4 (1375 g) [4], dlatego został on wybrany jako modelowy do wszystkich operacji niehobbystycznych. Założono, że w lotach rekreacyjnych modelowym BSP będzie Syma X5HW o wymiarach $33 \mathrm{~cm}$ x $33 \mathrm{~cm}$ x $11 \mathrm{~cm}$ i wadze $200 \mathrm{~g}$. Model wybrano ze względu na dobry stosunek jakości do ceny według portalu droniarze-sklep.pl.

Aby możliwe było określenie prawdopodobieństwa wystąpienia zdarzenia, przeanalizowano statystyki dotyczące incydentów lotniczych w Europie w $2018 \mathrm{r}$. [3]. Spośród 50 zdarzeń 15 dotyczyło naruszenia prywatności osób trzecich, 11 związane było z działalnością przestępczą, 17 dotyczyło kolizji z załogowym statkiem powietrznym, z czego 16 udało się uniknąć (w ośmiu przypadkach ruch lotniczy na lotnisku został wstrzymany). Cztery zdarzenia związane były z lotem nad infrastrukturą krytyczną, a trzy $\mathrm{z}$ wideofilmowaniem podczas imprez masowych (rys. 2). 


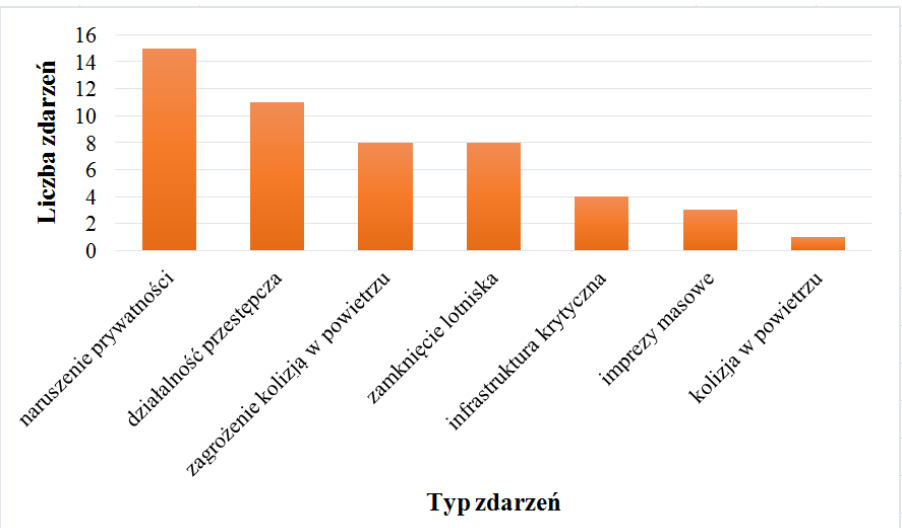

Rys. 2. Klasyfikacja incydentów lotniczych w Europie z udziałem BSP [3]

Wybrano monitorowanie infrastruktury liniowej jako przykład działalności, na którym przeprowadzona zostanie ocena ryzyka zagrożeń za pomocą dwóch metod. Proces oceny przeprowadzono również dla pozostałych obszarów, a wyniki zbiorcze przedstawiono w tab. 14. Zgodnie z przeprowadzoną klasyfikacją (rys. 2) $8 \%$ incydentów miało miejsce nad infrastrukturą krytyczną. W związku z tym w metodzie matrycowej przyporządkowano zdarzeniu trzeci stopień prawdopodobieństwa (prawdopodobnie nie wystąpi, ale jest to możliwe, bo wcześniej występowało rzadko). Dotkliwość szkód została oceniona na poziom B ze względu na stosunkowo dużą masę BSP oraz potencjalne szkody, jakie może spowodować, moga pośrednio dotyczyć wielu osób (np. utrata kontroli nad BSP podczas monitorowania linii energetycznych może spowodować przerwy w dostawach prądu). Operacja uzyskała więc kategorię 3B, co oznacza: „ryzyko akceptowalne przy założonym łagodzeniu ryzyka. Może wymagać decyzji na poziomie kierowniczym". Środkami łagodzenia ryzyka mogą być np. wybór odpowiednich warunków pogodowych do wykonania operacji, powiadomienie Polskiej Agencji Żeglugi Powietrznej (PAŻP) o planowanej trasie przelotu, czy ustawienie systemu powrotu do miejsca startu (Return To Launch, RTL) na odpowiedniej wysokości [9]. Ocena tej samej operacji metodą HRM przebiegała według schematu opisanego w rozdziale 2. Podpunkt dotyczący oceny organizacji został pominięty ze względu na duże zróżnicowanie systemów bezpieczeństwa w przedsiębiorstwach zajmujących się lotami bezzałogowymi i jest to ich cecha indywidualna. Największy wymiar bezzałogowca Phantom 4 jest mniejszy niż $1 \mathrm{~m}$, dlatego zgodnie z założeniami metody oczekiwana energia kinetyczna będzie $<0,7 \mathrm{~kJ}$. W związku z tym, że wybrany fragment infrastruktury liniowej na odcinku $2,5 \mathrm{~km}$ wymaga wykonania operacji poza zasięgiem wzroku (Beyond Visual Line Of Sight, 
BVLOS) i odbywa się głównie nad obszarem rolniczym (rys. 3), uzyskano drugą klasę ryzyka naziemnego (GRC).

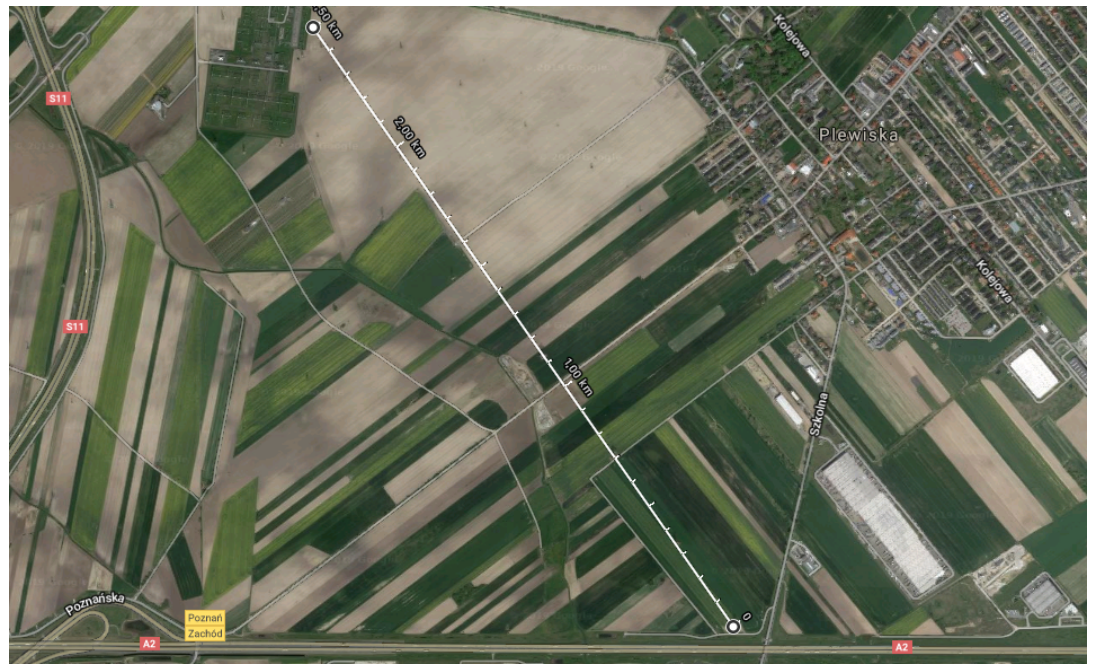

Rys. 3. Widok z góry na planowaną trasę lotu monitorującego [5]

Operator ma dostęp do planu reagowania kryzysowego, udostępnionego przez firmę zlecającą monitoring, ale nie miał możliwości jego sprawdzenia, dlatego odporność tej bariery jest średnia, bezzałogowiec nie posiada spadochronu ratunkowego, nie ma też zabezpieczenia technicznego (tab. 6). GRC $\leq 7$, więc operacja może być uznana za dostatecznie bezpieczną według metodologii SORA. Uwzględniając potencjalna śmiertelność (loty nie są wykonywane nad obszarem zaludnionym), otrzymano poziom SAIL $=0$ (tab. 7). Następnie dokonano oceny pod względem przestrzeni powietrznej. Lot wykonywany jest w strefie ruchu lotniskowego lotniska wojskowego (Military Aerodrome Traffic Zone, MATZ) lotniska Poznań-Krzesiny, na wysokości ok. 150 - 200 ft., co pozwala na określenie wskaźnika kategorii przestrzeni powietrznej równego 6 (tab. 8). Pozwoli to rozpocząć procedurę wyznaczania klasy $\mathrm{ARC}=3$ (tab. 9). Klasa trzecia pozwala na zdefiniowanie poziomu pewności i nienaruszalności bezpieczeństwa, wynoszącego w tym wypadku 4 (tab. 10), co prowadzi do umiarkowanych wymagań dotyczących mitygacji ryzyka zagrożeń. Należy położyć duży nacisk na kompetencje operatora i koordynację załogi oraz zastosować środki mające zapewnić poprawne działanie systemu bezzałogowego w przypadku pogorszenia działania urządzeń zewnętrznych, a także dostosować procedury operacyjne do konkretnej operacji (tab. 12). Po sprawdzeniu wykonalności zadanych barier 
i scenariuszy operacyjnych, określa się poziom integralności i pewności, co jest, jak punkt pierwszy metody, zadaniem operatora i wymaga dostosowania do sytuacji rzeczywistej. W sposób analogiczny przeprowadzono analizę dla monitorowania zanieczyszczenia powietrza, fotografii i wideofilmowania, rolnictwa precyzyjnego oraz lotów rekreacyjnych na terenie zabudowanym (tab. 11).

Tabela 11

Porównanie obszarów analiz dostępnymi metodami

\begin{tabular}{|l|l|l|l|}
\hline & $\begin{array}{c}\text { Metoda } \\
\text { ULC }\end{array}$ & $\begin{array}{c}\text { Metoda JARUS } \\
\text { GRC }\end{array}$ & Metoda JARUS ARC \\
\hline Infrastruktura liniowa & $3 \mathrm{~B}$ & 0 & IV \\
\hline Zanieczyszczenie powietrza & 4B & V & VI \\
\hline Fotografia & 3A & VI & IV \\
\hline Rolnictwo & 11 & 0 & IV \\
\hline Loty rekreacyjne & 5B & III & IV \\
\hline
\end{tabular}

W każdym obszarze działalności BSP, w którym w jednym z członów metody proponowanej przez JARUS (GRC lub ARC) pojawił sie poziom SAIL > IV, w metodzie ULC określono nieakceptowalny poziom ryzyka zagrożeń. Dla monitorowania zanieczyszczenia powietrza oraz fotografii i wideofilmowania uzyskano współmierne rezultaty w obu metodach. W lotach rekreacyjnych metoda ULC okazała się bardziej restrykcyjna i wskazała na poziom nieakceptowalny, podczas gdy zarówno GRC, jak i ARC były na poziomie tolerowanym. W dwóch przypadkach, kiedy GRC wynosiło 0, a ARC IV, metody nie dały porównywalnych rezultatów, gdyż w jednym przypadku metoda ULC wskazała akceptowalny, a $\mathrm{w}$ drugim tolerowany poziom ryzyka. Można stwierdzić, że metoda ULC kwalifikuje poziom ryzyka jako wyższy niż metoda JARUS, co jest pozytywne ze względu na bezpieczeństwo, ale nie spełnia wymagań szybko rozwijającej się branży.

\section{Podsumowanie}

W celu porównania dostępnych metod wybrano pięć obszarów analiz. Sformułowane zagrożenia przeanalizowano zgodnie z metodykami i porównano wyniki. Metoda ULC jest metodą reaktywną [2] (bazującą na zdarzeniach przeszłych), co nie jest odpowiednie dla specyfiki stosunkowo nowego i dynamicznie rozwijającego się rynku BSP w Polsce. W przeprowadzonej analizie, konieczne było posłużenie się statystykami rynku europejskiego, co niedokładnie odwzorowuje sytuację na rynku polskim. W bazie Państwowej Komisji Badania Wypadków 
Lotniczych nie ma dostatecznej liczby zgłoszeń, aby zapewnić podstawę dla metody opierającej się na częstotliwości występowania podobnych zdarzeń w przeszłości. Metoda proponowana przez JARUS jest bardziej złożona i ułatwia znalezienie dokładnego obszaru, w którym konieczna jest poprawa poziomu ryzyka, a także zapewnia narzędzia do jego mitagacji. Jest jednak skomplikowana dla często występujących w branży firm jednoosobowych. Dlatego konieczne jest opracowanie nowych metod zapewniających bezpieczeństwo i spełniających oczekiwania użytkowników.

\section{Literatura}

1. Fellner A., Mańka A.: Dostosowanie metody FMEA do wymagań branży lotniczej. Zeszyty Naukowe Politechniki Śląskiej. Seria Transport. 2015.

2. Galant M.: Ograniczenie ryzyka zagrożeń w lotnictwie ogólnym przez zastosowanie systemu monitorującego stan psychofizyczny pilota. Rozprawa doktorska. Politechnika Poznańska, Poznań 2017.

3. https://www.dedrone.com/resources/incidents/

4. https://uavcoach.com/faa-drone-data/

5. https://www.google.pl/maps/

6. International Civil Aviation Organization, Manual on Remotely Piloted Aircraft Systems (RPAS), Doc. 10019 ICAO, first edition 2016.

7. JARUS guidelines on Specific Operations Risk Assessment (SORA) 2017

8. Klich E.: Bezpieczeństwo lotów. Wydawnictwo Instytutu Technologii Eksploatacji, Radom 2011.

9. Rozporządzenie Ministra Transportu, Budownictwa i Gospodarki Morskiej z dnia 26 marca 2013 r. w sprawie wyłączenia zastosowania niektórych przepisów ustawy Prawo lotnicze do niektórych rodzajów statków powietrznych oraz określenia warunków i wymagań dotyczących używania tych statków.

10. Urząd Lotnictwa Cywilnego: Krajowy Plan Bezpieczeństwa 2017-2020, Warszawa 2017. 